Invited review

\title{
Optimizing measurements of sediment transport in the intertidal zone
}

\author{
Evelien Brand*, Margaret Chen, Anne-Lise Montreuil \\ Vrije Universiteit Brussel, Pleinlaan 2, 1050 Elsene, Belgium
}

\section{A R T I C L E I N F O}

\section{Keywords:}

In-situ measurements

Field investigations

Sediment transport

Morphodynamics

Beach topography

\begin{abstract}
A B S T R A C T
The intertidal beach is very dynamic and is characterized by high sediment transport rates which may result in large topographic changes. Measuring techniques are well developed for both sediment transport and beach topography but the quantification of transport remains difficult. This paper provides an in-depth review of studies that cross-checked sediment transport measured underwater to transport derived from topographic change and/or predictive formulas to optimize future measuring campaigns in the intertidal zone. Based on these studies it is strongly recommended to measure sediment transport at multiple locations in the intertidal zone, although it is recognized that this is costly. When the suspended sediment is mixed and vertically stratified, it should be gauged over the entire water column. Acoustic backscatter intensity can be used for this purpose but needs to be corrected for grain size and turbulence. When cross-checking measured sediment transport rates with beach volume changes topographic profiles may not be sufficient. Instead, laser scanning of the beach is recommended. Additionally, valuable insights can be obtained from continuously measuring the beach topography. When beach topography is only measured during low tide, wind-driven transport should be taken into account during energetic conditions. It is deemed necessary to improve sensors to measure bed load transport and suspended sediment transport close to the bed and to further improve formulas to predict sediment transport. With the suggestions given in this paper it is encouraged to perform field investigations of sediment transport in the intertidal zone to improve our knowledge of the intertidal beach morphodynamics.
\end{abstract}

\section{Introduction}

The intertidal beach, the zone between low and high tide (Fig. 1), is very dynamic. It is subject to most of the wave breaking and swash action, resulting in high sediment transport rates. Besides the effect of waves, sediment is also transported by tidal currents, residual currents, and wind. If gradients in sediment transport exist, this will result in either erosion or deposition of sediment, which in turn will influence the hydrodynamics and sediment transport. This cycle of marine (and aeolian) forcing, sediment transport, and beach morphology is referred to as the beach morphodynamics (Masselink et al., 2011).

Sediment transport in the intertidal zone has been a topic of scientific interest since the middle of the 20th century (e.g. Bagnold, 1947). Most of the research was directed to theoretical studies and laboratory wave tank investigations (Hails, 1974), but there were also a few pioneering field studies in the 20th century (e.g. Inman, 1949; Terry, 1951; Watts, 1953; Caldwell, 1956; Thornton, 1968; Komar and Inman, 1970; Jaffe et al., 1984; Kraus, 1987). It was soon acknowledged that restrictive physical factors, such as large waves and heavy turbulence, limited in-situ measurements and that this was most likely the cause of the poor correlations that were found between field data and laboratory results and theoretical predictions (Hails, 1974). Techniques to measure sediment transport evolved continuously and advanced sensors have been developed (e.g. Mikkelsen and Pejrup, 2001; Turner et al., 2008). As a result, our qualitative understanding of sediment transport in the intertidal zone has greatly improved (e.g. Aagaard et al., 2004; Aagaard et al., 2005; Houser et al., 2006).

The two main modes of sediment transport are bed load transport and suspended load transport. Bed load transport is defined as gliding, rolling, and saltating particles in close contact with the bed, while suspended load transport is defined as the transport of particles in the water column by turbulence-induced drag forces (Van Rijn, 1993). Sediment transport rates are generally highest close to the bed (Kraus, 1987; Tonk and Masselink, 2005; Cartier and Héquette, 2015), but energetic waves or strong tidal currents may mix the sediment through the entire water column (e.g. Brand et al., 2019b). In general, it is acknowledged that cross-shore sediment transport is controlled by the balance between onshore transport due to wave skewness and offshore transport by undertow, but the ratio of onshore/offshore transport is determined by the wave energy (e.g. Voulgaris et al., 1996; Masselink et al., 2008; Brand et al., 2019b). This difference between onshore and offshore transport over individual waves builds up over a tidal cycle

\footnotetext{
* Corresponding author.

E-mail addresses: Evelien.Brand@vub.be (E. Brand), Margaret.Chen@vub.be (M. Chen), Anne-Lise.Montreuil@vub.be (A.-L. Montreuil).
} 


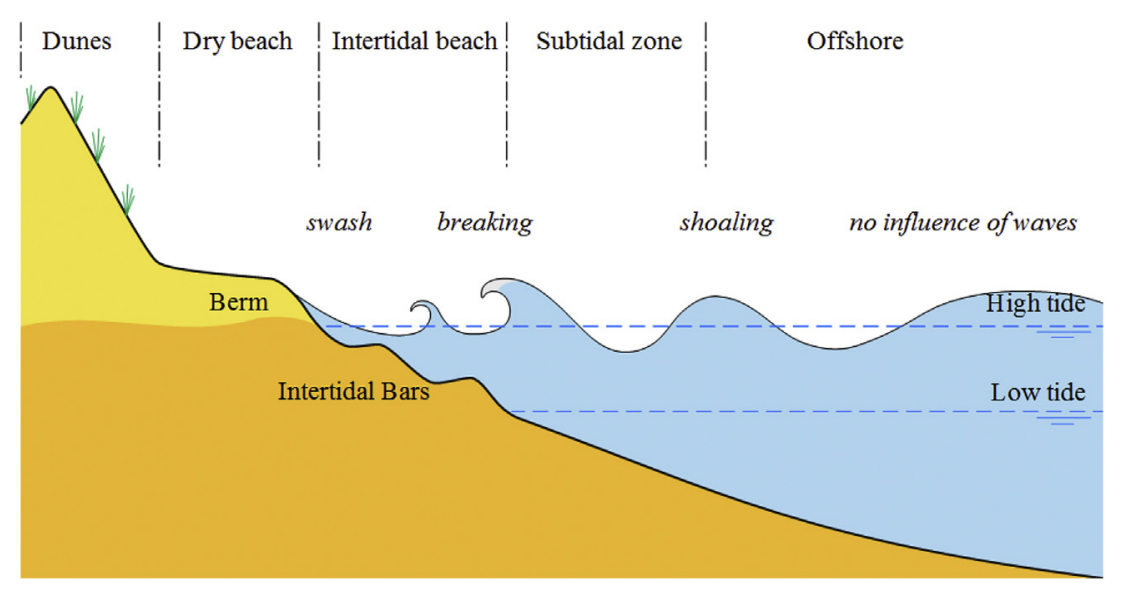

Fig. 1. Schematized wave propagation across the different beach zones.

and may result in large topographic changes.

Quantifying net sediment transport remains difficult, while reliable and accurate measurements of sediment transport rates are essential to better understand intertidal beach morphodynamics, to manage the beach, and to calibrate and validate sediment transport models. Field measurements are often labour intensive, time consuming, and costly. Thus, it is necessary to optimize field measurements to obtain accurate results with limited resources. To our knowledge, no literature exists that reports the advantages and disadvantages of techniques to measure sediment transport in the intertidal zone of sandy beaches. Therefore, this paper provides an in-depth review of measuring techniques, in terms of their advantages, disadvantages, and performance in the field, which leads to some recommendations for future measuring campaigns in the intertidal zone. The accuracy of measured transport rates cannot be determined or validated without cross-checking of sediment transport rates from different methods or approaches. Therefore, this paper mainly addresses studies that compared measured sediment transport rates to transport rates derived from topographic change and/or predictive formulas.

\section{Measuring techniques and predictive formulas to quantify sediment transport}

\subsection{Suspended load}

The first measurements of sediment transport in the intertidal zone date back to the middle of last century. The first techniques that were used are extensively described by Hails (1974). Fig. 2 illustrates the evolution of the most common or promising techniques since then, based on the references used in this section. Solid lines represent periods of time when techniques were used for measurements in the intertidal zone. Dashed lines indicate that techniques were upcoming or that the use decreased. The main shift in sediment transport measurements has been from manual sampling to the use of sensors. In this section the techniques to measure suspended sediment transport will be described, in the next section techniques to measured bed load or total load are presented.
Suspended sediment transport can be quantified by combining measurements of flow velocity and suspended sediment concentration, assuming that sediment particles have the same velocity as the water that carries them. Flow velocity measurements are most often carried out with acoustic (e.g. Acoustic Doppler Current Profilers, ADCP, and Acoustic Doppler Velocimeters, ADV) or electromagnetic current meters (ECM). Techniques to measure suspended sediment concentrations are discussed below.

Taking water samples and filtering them is a classic technique to determine suspended sediment concentrations. Many samplers, such as simple bottles, trap samples, or more advanced samplers like pump samplers exist. However, taking water samples is very time-consuming and it is difficult to take water samples in the intertidal zone, especially under breaking waves (Hails, 1974).

Since the eighties, optical backscatter sensors (OBS) are most often used to determine suspended sediment concentrations (e.g. Jaffe et al., 1984; Aagaard et al., 2004; Aagaard et al., 2005; Houser et al., 2006; Masselink et al., 2009). These sensors were developed by Downing et al. (1981). They emit an infra-red light and record its backscatter, which is a measure for turbidity. They measure with a frequency up to $10 \mathrm{~Hz}$, so they are suitable to study very fast variations in suspended sediment concentrations. They can be deployed in the field for a long time (weeks to months). However, they are subject to biofouling and thus need to be cleaned regularly or they need to be equipped with a mechanical wiper. A limitation of OBS is that they only perform point measurements, so multiple OBS are needed to measure a profile of suspended sediment concentration over the water column.

Recently attempts have also been made to measure the suspended sediment concentration in the intertidal zone based on acoustic backscatter (Aagaard et al., 2012). Before, this method was only used in river, estuary, and bay environments (e.g. Gartner, 2004; Merckelbach and Ridderinkhof, 2006; Weiss et al., 2015). The major benefit of acoustic sensors is that they provide a vertical profile of suspended sediment concentrations. A limitation is that acoustic sensors are not capable of detecting particles that are smaller than the wavelength of the acoustic pulse, which depends on the type of acoustic sensor.

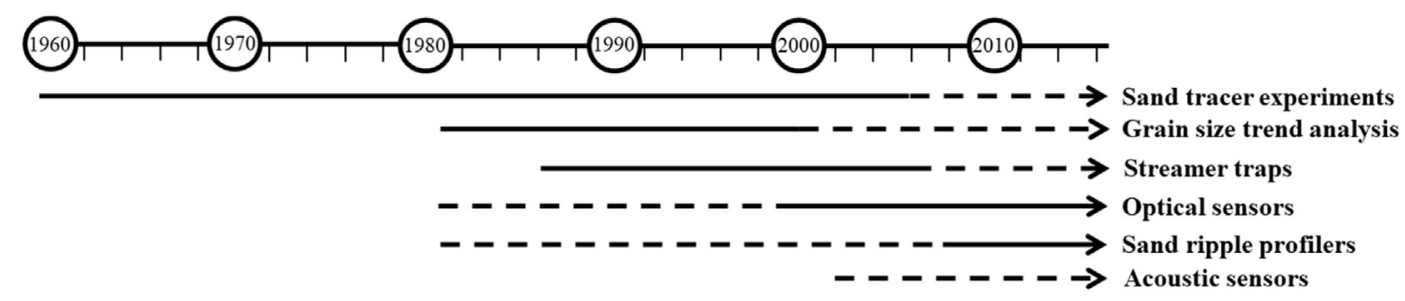

Fig. 2. Timeline of measuring techniques for sediment transport from the 1960s until now. Dashed lines indicate limited use. 
The response of optical and acoustic sensors strongly depends on particle characteristics, such as size, shape, and colour. The sensors thus need to be calibrated with samples from the study site to convert backscatter to suspended sediment concentrations. A major problem regarding this calibration is that it is specific for the particle size of the sample. Both optical and acoustic sensors are not able to differentiate between changes in concentration and changes in particle size distribution. Optical sensors are more sensitive to clay and their response to particles of $2 \mu \mathrm{m}$ is 50 times greater than to particles of $100 \mu \mathrm{m}$ for the same concentration (Battisto et al., 1999). Acoustic sensors, on the other hand, are more sensitive to sand (Thorne et al., 1991).

Furthermore, acoustic sensors are sensitive to turbulence (Nauw et al., 2014). Under strong turbulent conditions scatterers may no longer be randomly distributed and the Kolmogorov wavelength can become smaller than the wavelength of the acoustic pulse. In that case, small scale turbulent eddies of Kolmogorov scale disturb the measurements of suspended sediment concentrations. Therefore, an additional calibration of acoustic sensors is needed under turbulent conditions, as described in Merckelbach and Ridderinkhof (2006). Only a few studies have used acoustic sensors to measure suspended sediment concentrations in turbulent conditions (Nauw et al., 2014). An example of the effect of turbulence on measurements of suspended sediment concentrations is given in Fig. 3, for which it is assumed that the OBS results are reliable, which was validated with water samples. It indicates that acoustic sensors may significantly overestimate suspended sediment concentrations under turbulent conditions. It is uncertain to what extent acoustic sensors can be used in the highly dynamic intertidal zone.

\subsection{Bed load and total load}

From field measurements it is known that bed load transport can make up more than half of the total load transport (Tonk and Masselink, 2005; Masselink et al., 2008). Measurements of bed load transport are thus key when studying the intertidal beach morphodynamics. However, it is difficult to measure bed load transport in-situ. Instead, predictive formulas are often used to estimate bed load transport (e.g. Sedrati and Anthony, 2007; Masselink et al., 2009). Both field techniques and predictions to quantify bed load transport are discussed here.

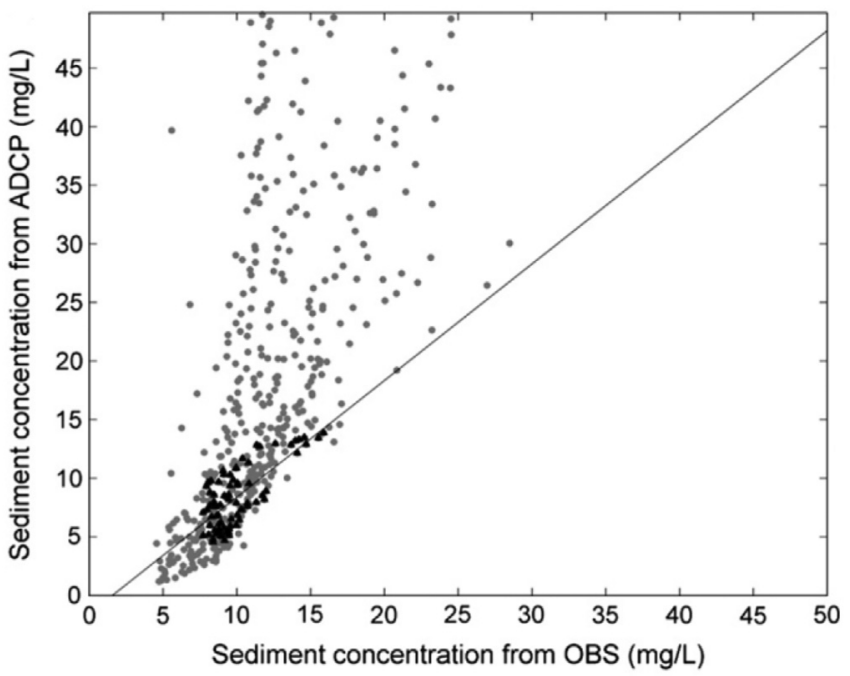

Fig. 3. Suspended sediment concentration derived from acoustic backscatter compared to the suspended sediment concentration derived from OBS. These measurements were carried out in a tidal inlet, the Marsdiep inlet (The Netherlands). Black (grey) points represent data for which the depth-averaged velocity $<0.5 \mathrm{~m} / \mathrm{s}(>0.5 \mathrm{~m} / \mathrm{s})$. Drawn is the linear fit through the black data points (Nauw et al., 2014).

\subsubsection{Qualification of total load transport}

Firstly, measuring techniques exist to get insight in the spatial pattern of the total load transport. Grain size trend analysis is a relatively easy tool, suitable for marine environments in which there is no a priori information on sediment transport (e.g. Masselink, 1992; Pedreros et al., 1996; Delgado et al., 2002; Poizot et al., 2006). For this analysis, invented by McLaren (1981), grain size, sorting, and skewness in grain size are determined from sediment samples. It is assumed that spatial variations in grain size parameters are the result of sediment transport processes such as abrasion, selective transport and mixing of sediment (McLaren, 1981; McLaren and Bowles, 1985; Gao and Collins, 1991; Le Roux, 1994). McLaren (1981) stated that sediment becomes better sorted and either finer and more negatively skewed or coarser and more positively skewed in the direction of transport. This theory was later modified by Gao and Collins (1991, 1992, 1994) for multidirectional sediment transport. This resulted in not two but eight possible cases of grain size trends (Gao and Collins, 1994). Le Roux (1994) modified the method of grain size trend analysis method for sampling locations that are not within a perfect grid. A limitation of this method is that it is not quantitative. Furthermore, the period of time that is represented by the calculated transport directions is uncertain (Gao and Collins, 1992).

Sand tracer experiments can be used to monitor patterns of sand transport on a shorter timescale. Beach sand is tagged with a fluorescent paint and after a certain amount of time beach sediment samples are taken for which the fraction of tagged grains is determined (Medvedev and Aibulatov, 1956; Wright, 1962). Tracer experiments are usually carried out over a few hours up to one tidal cycle, because the sand will be spread too far afterwards. Although in some cases they can be used to quantify sediment transport (Komar and Inman, 1970; FernándezFernández et al., 2016), these experiments are often qualitative due to low overall tracer recovery (Levoy et al., 1997; Voulgaris et al., 1998; Stépanian et al., 2001; Tonk and Masselink, 2005; Sedrati and Anthony, 2007). Nevertheless, they provide valuable insights in the transport direction and they can be used to support suspended sediment transport and topographic measurements (Tonk and Masselink, 2005, FernándezFernández, 2016). An example of this is Fig. 4, which illustrates how a sand tracer experiment revealed changes in sediment transport direction across a beach. An added value of both grain size trend analysis and tracer experiments is that they reveal total load transport, including the bed load transport which remains difficult to measure (Tonk and Masselink, 2005). Furthermore, they can be used in both calm and energetic conditions. A downside is that sand tracer experiments are time-consuming.

\subsubsection{Quantification of bed load transport}

Secondly, techniques exist to quantify bed or total load transport. One of the oldest techniques to measure suspended and bed load transport are streamer traps, or total load traps, developed by Kraus (1987). These traps are made of a long, rectangular, sieve cloth bag that can be mounted on a steel rack. In the past they were often used to measure the vertical and lateral distribution of the sand transport rate in the intertidal zone (e.g. Levoy et al., 1994; Hughes et al., 1997; Masselink and Hughes, 1998). Nowadays their use is limited due to some drawbacks associated with this method. For instance, the traps need to be emptied manually every few minutes, which makes this method labour intensive and unsuitable for long-term measurements (Kraus, 1987; Tonk and Masselink, 2005). Also, the use of streamer traps is restricted to the intertidal and lower swash zone and to calm wave conditions because they need to be deployed manually (Kraus, 1987; Tonk and Masselink, 2005). Furthermore, streamer traps are prone to oversampling due to initial stirring and undersampling due to gaps between the bed and the sampler mouth and obstruction of bed load transport (Masselink et al., 2009).

Conductivity sensors (Conductivity Concentration Meter: CCM) were developed to measure high concentrations of sand $(<2 \mathrm{~kg} / \mathrm{l}$, 

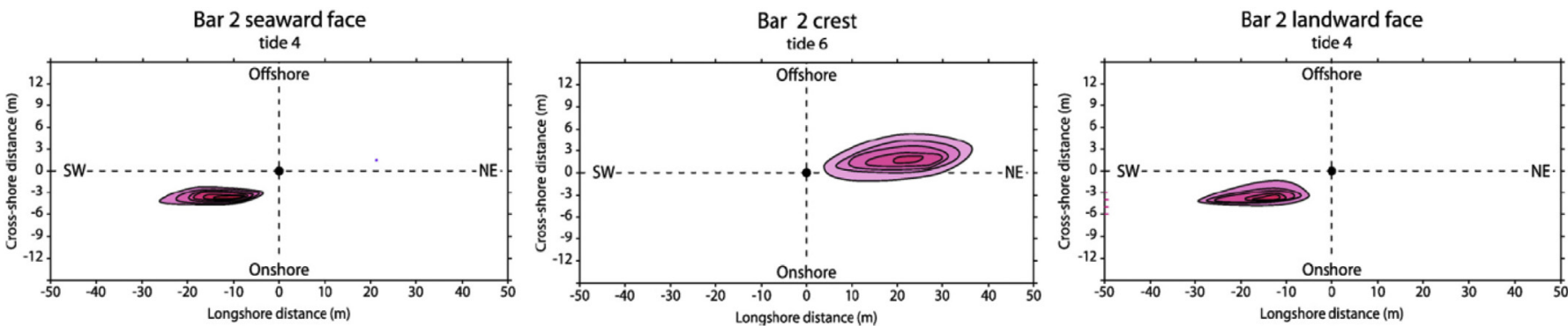

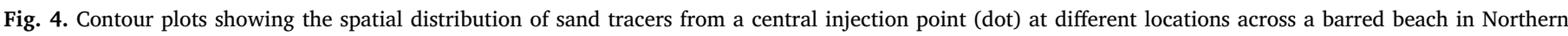

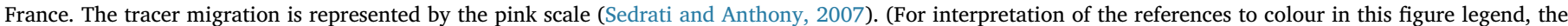
reader is referred to the web version of this article.)

Ribberink and Al-Salem, 1992) to quantify sediment concentrations in the direct vicinity of the bed. These sensors have mainly been deployed to study sediment transport under sheet flow in laboratory studies (McLean et al., 2001; Lanckriet et al., 2013). Although these sensors have been used in the field (Dohmen-Janssen and Hanes, 2002), they are more suitable for laboratory experiments as their elevation above the bed should be constant.

Another method to measure bed load transport is the bed-form tracking of sand ripples, where acoustic profilers (side scan sonar) measure bed profiles at successive time intervals. From these scanned profiles the ripple migration is known from which bed load transport rate can be computed. This is thus an indirect way to estimate bed load transport based on the migration of bed forms and as a result the obtained transport rates may not always be accurate. This method has been tested in flumes (Simons et al., 1965; Thorne et al., 2009) and river or estuary environments (Havinga, 1982; Bell et al., 1998) and has more recently also been used in a beach environment (Masselink et al., 2008).

\subsubsection{Prediction of bed load transport}

Besides measuring techniques, several predictive formulas for both suspended and bed load exist (e.g. Inman and Bagnold, 1963, CERC, 1984, Bailard, 1984, Kamphuis, 1991, Van Rijn, 2014). Some of them are based on wave characteristics (CERC, 1984), sometimes in combination with beach characteristics (Kamphuis, 1991). An advantage of these formulas is that they can be used across the entire intertidal zone. The main drawback of these formulas is that they should be calibrated with empirical coefficients, so the quality of the results depends among others on the quality of field data. In ideal conditions the CERC (1984) formula has an accuracy of $\pm 30-50 \%$ (Wang et al., 2002) and the Kamphuis (1991) formula 40\% (Schoonees and Theron, 1996). Other simpler formulas assume that the sediment flux is related to the velocity to a power, usually 3 or 5 . The Bailard (1984) equation, based on Bagnold's (1963) energetic approach to sediment transport is one of the most widely applied formulas of this type. It has an accuracy of approximately $70 \%$ (Schoonees and Theron, 1995). It works best for energetic conditions (Thornton et al., 1996; Gallagher et al., 1998) but it can also work for calm conditions (Hoefel and Elgar, 2003). Formulas based on flow velocity are less applicable to the higher intertidal and swash zone (Butt et al., 2005; Masselink and Russell, 2006).

\subsection{Net transport reflected on topographic changes}

Net sediment transport rates can also be derived from topographic changes, hence the most common and most promising techniques to measure beach volume changes are described in this section. Beach topography has been measured for centuries, but the first measurements with an accuracy in the order of centimetres date back to the 1960s. Fig. 5 presents a timeline of the measuring techniques that have been used since then based on the references mentioned in this section. Surveying profiles has been popular since the beginning. In the 1960s rods were used to measure profiles of beach topography. Although still functional, rods have largely been replaced by the more accurate and time efficient Real-Time Kinematic GPS (RTK-GPS) and total station since the 2000s. Recently, techniques to measure the topography with a higher spatial or temporal resolution, such as the terrestrial laser scanner, have been developed.

A broad range of methods exist to measure topography, but not all are suitable for the intertidal beach. Emery (1961) proposed a simple method to measure beach topography using two rods with elevation markings. Their alignment and intersection with the horizon allows determining differences in bed level. The principle has stayed the same over time, although some improvements have been made (Andrade and Ferreira, 2006). The measurement errors associated with rods are not well documented, but they are less accurate than modern techniques. However, thanks to the simplicity and the low cost, rods have long been used to survey cross-shore beach profiles (e.g. Houser et al., 2006). Nowadays, profiles are more often measured with a total station (Masselink et al., 2008; Aagaard et al., 2012) or an RTK-GPS (Aagaard et al., 2005). A total station has a vertical accuracy in the order of millimetres. The accuracy of the RTK-GPS is $2-3 \mathrm{~cm}$ for the $\mathrm{x}, \mathrm{y}$ and $\mathrm{z}$ coordinates combined, but is more practical to use than the total station. A GPS can also be mounted on a vehicle for faster surveys (e.g. Parisot et al., 2009). Typically, these methods are used to survey crossshore profiles, resulting in $2 \mathrm{D}$ data.

It is popular to measure cross-shore profiles because it is relatively easy and equipment is low-cost. Generally, one central profile with additional profiles on each side is surveyed from the low water line to the foot of the dune every day during low tide. However, large differences in topographic response to the incoming hydrodynamics may exist alongshore (Eamer and Walker, 2013; Fernández-Fernández et al., 2016; Cohn et al., 2017). Therefore, profiles may be insufficient to represent the beach morphology, especially when the profile spacing is $>100 \mathrm{~m}$ (Swales, 2002; Bernstein et al., 2003; Pietro et al., 2008). Theuerkauf and Rodriguez (2012) studied the impact of transect location on the calculated volumes. They found that the profile-based volumetric change becomes inaccurate with the increase of along-beach morphologic variability, such as the presence of beach cusps, beach nourishments, or pockets of anomalous erosion/accretion.

The development of terrestrial laser scanning technology has enabled to collect high resolution, instantaneous, and accurate topographic data of large areas in 3D. The system composed of a transmitter that generates a laser beam which is reflected back to a receiver after hitting the bed surface. It can be mounted on a static or mobile platform, like a vehicle (Incoul et al., 2014). When the laser is used statically an additional rotation axis can also make the sampling three-dimensional (Jaud et al., 2011; Vousdoukas et al., 2014; Vos et al., 2017; Vos et al., 2019). Terrestrial laser scanners have been used to measure beach topography profiles since the late 1980s (Huising and Gomes Pereira, 1998). Major advantages of laser scanning are that the accuracy is a few millimetres and that high-density topographic measurements are obtained. The main limitation is that data processing is time 


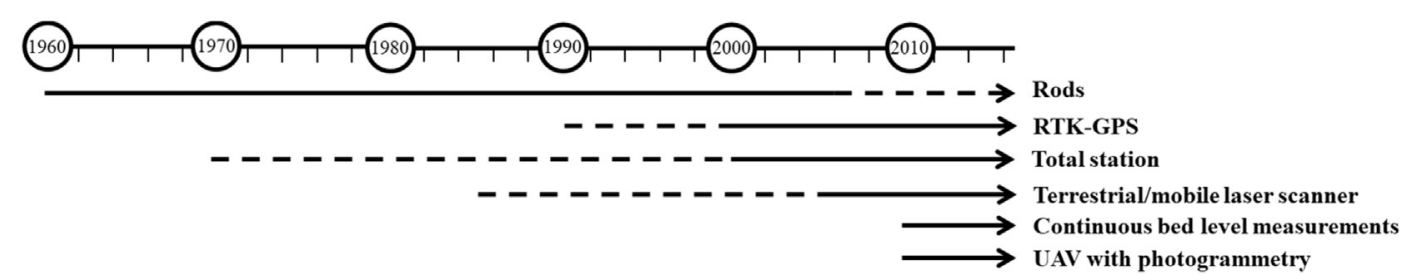

Fig. 5. Timeline of measuring techniques for intertidal beach topography from the 1960s until now. Dashed lines indicate limited use.

consuming, because large datasets are generated. With LiDAR (LIght Detection And Ranging, airborne laser scanning) and satellite imagery it is also possible to survey beach topography with a high point density, but the high costs make these options less suitable for local scales and rapid or frequently repeated surveys.

Recently, improvements have also been made in determining the beach topography with photogrammetry, based on measurements with a photo camera on an Unmanned Aerial Vehicle (UAV; J.A.J. Berni et al., 2009b, Delacourt et al., 2009, Jaud et al., 2011, Westoby et al., 2012). With UAV local scale, rapid, and frequent surveys are economically feasible for the coastal zone, but a drawback is that drones typically cannot be used in energetic wind conditions.

\subsection{Advantages and drawbacks of the most common techniques}

The most common measuring techniques to quantify sediment transport in the intertidal zone were introduced in this section. Other techniques exist for laboratory experiments or to measure beach topography on a larger scale (e.g. LiDAR and Argus), but only techniques that were previously used to quantitatively compare measured sediment transport and beach volume changes were included here. The advantages and drawbacks of the techniques mentioned that are most common or promising for measuring sediment transport in the intertidal zone are summarized in Table 1 .

\section{Cross-checking suspended load measurements}

Suspended sediment transport is generally measured with flow velocity sensors and an array of OBS at the low water line. Many variations to this measuring set-up exist. To cross-check the measured transport quantitatively it is usually averaged over a tidal cycle and compared to volume changes observed in the intertidal zone. Most studies that compared sediment transport and beach volume changes found similar trends between the two, but they were often only related in a qualitative way (Aagaard et al., 2004; Aagaard et al., 2005; Houser et al., 2006; Sedrati and Anthony, 2007). Here, quantitative comparisons will be reviewed in order to determine the best set-up to quantify suspended sediment transport.

Jaffe et al. (1984), a pioneer in this type of research, quantitatively compared hourly bed level changes across a profile with changes predicted from convergences and divergences in cross-shore suspended sediment transport. This was done based on observations with five OBS at different elevations (0.1-0.6 m above the bed) during a high tide in storm conditions. Their number of observations was limited to six and only three of these observations were in the intertidal zone, the others were located in the subtidal. The measured suspended sediment fluxes were sometimes in a different direction and often of a different magnitude than what the topographic changes suggest. Nevertheless, profile changes and suspended sediment fluxes generally exhibited a similar trend, which made Jaffe et al. (1984) among the first to prove the value

Table 1

Advantages and drawbacks of the most common techniques.

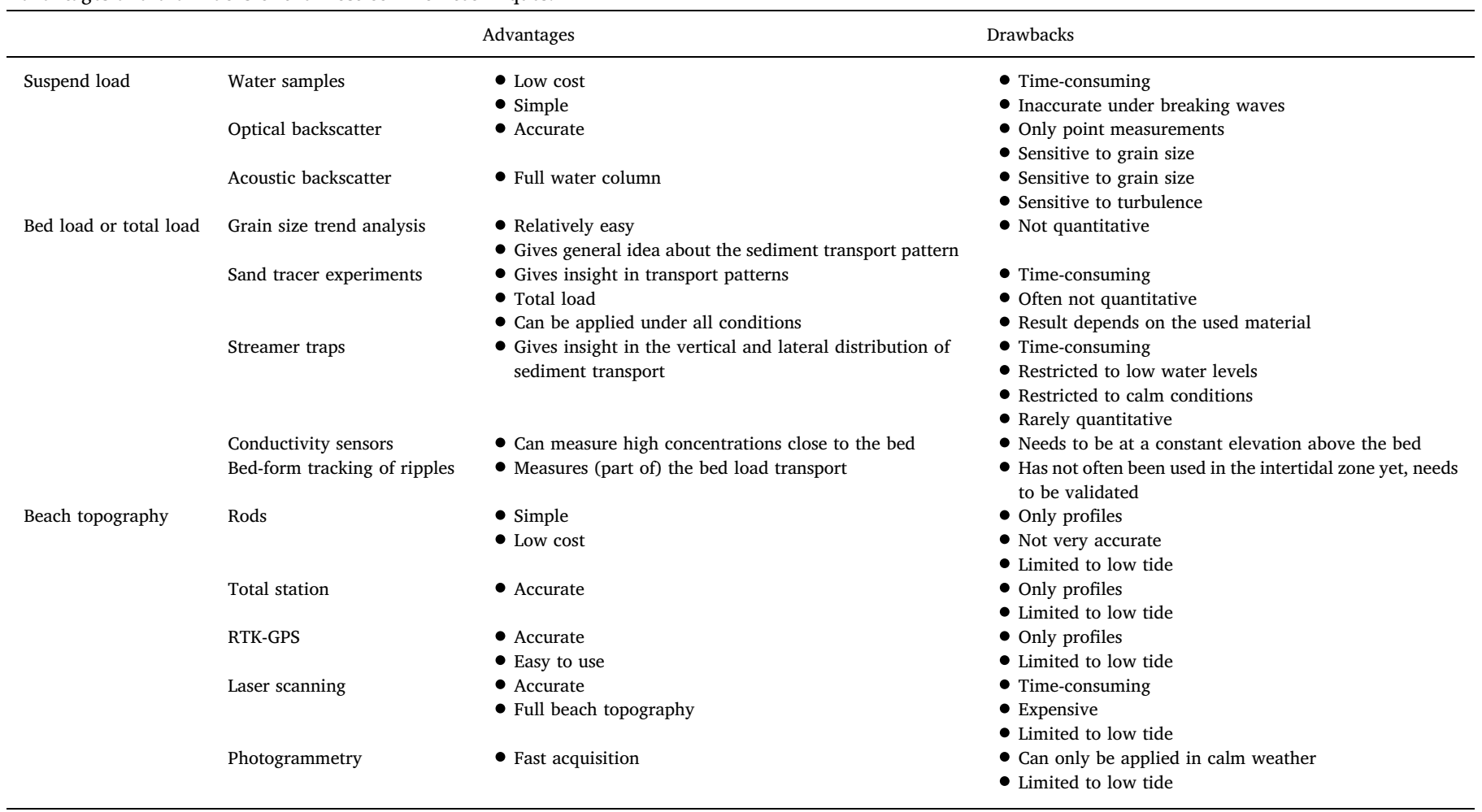




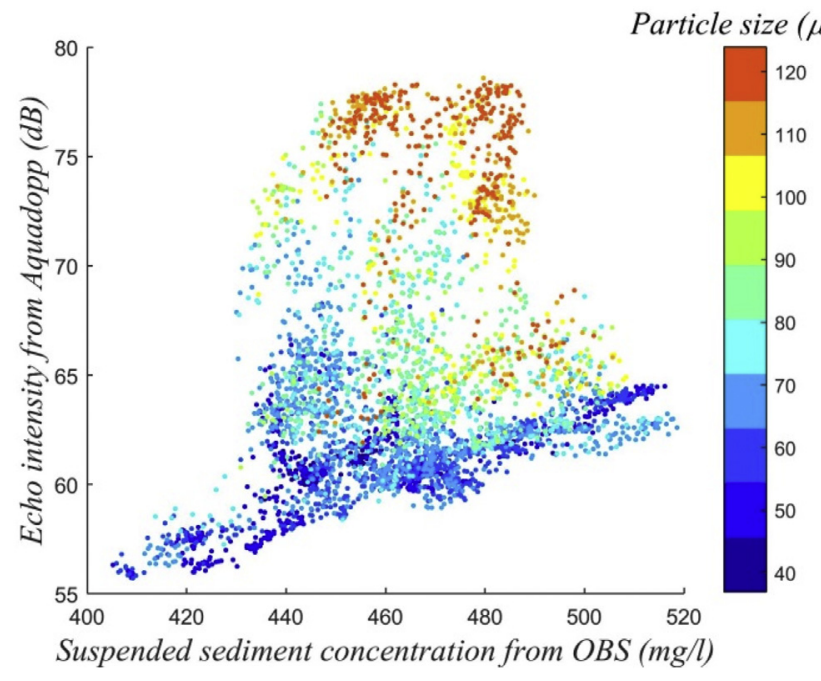

Fig. 6. The effect of particle size (colours) on acoustic backscatter intensity based on measurements around the low water line on a sandy beach at Groenendijk, Belgium (Brand et al., 2019a).

of OBS in intertidal beach research. This was later reaffirmed by many other studies, for example based on comparisons between OBS and streamer traps (e.g. Tonk and Masselink, 2005).

Years later, Masselink et al. (2008) also quantitatively compared measured sediment transport rates and beach volume changes. They measured suspended sediment transport with OBS at five locations across the intertidal zone and bed load transport with two sand ripple profilers. Volume changes were derived from three cross-shore topographic profiles. Topographic changes were found to be 1.5 to 3 times larger than the net sediment transport. Although this is not a perfect agreement, it is in the same direction and order of magnitude. These good results were attributed to the inclusion of the sand ripple profilers and the use of 13 OBS over $20 \mathrm{~cm}$ at one of the frames. This high coverage allowed to accurately estimate suspended sediment concentrations over this distance. Such a small array of OBS is easily realised and may be sufficient when suspended sediment transport is concentrated near the bed. Recently, the Argus Surface Meter (ASM) was developed which is even more convenient to measure suspended sediment concentrations over a small water column. It has an array of optical sensors embedded and is especially designed to measure several decimetres of the water column with a centimetre interval. This equipment has been used in rivers (Furgerot et al., 2016), lakes (Vijverberg et al., 2011), estuaries (Albers and von Lieberman, 2010), and laboratory experiments (Zhang et al., 2018), but has yet to be applied in the intertidal zone.

For macro-tidal beaches, where several meters of water can inundate the beach, the top part of the water column is more difficult to survey. It is essential to survey the entire water column though when the suspended sediment is mixed but vertically stratified. For these beaches it is desired to further investigate the use of acoustic sensors, that are often already deployed to survey the flow velocity, to determine suspended sediment concentrations. Aagaard et al. (2012) were among the first to also use acoustic sensors to measure suspended sediment transport in the intertidal zone and relate it to topographic changes. They obtained a reasonably good correlation between suspended sediment concentrations from acoustic and optical backscatter. The difference in the means was only $5 \%$, but the variance was significantly larger. Similar trends in measured sediment transport and observed topographic changes were found, but they were not related in a quantitative way. Nevertheless, this study suggests that acoustic sensors are able to quantify suspended sediment transport rates in the highly dynamic zone. This was reaffirmed by the study of Brand et al. (2019b) who quantified sediment transport over several meters of water based on optical backscatter in the lower $50 \mathrm{~cm}$ of the water column and acoustic backscatter in the upper few meters. They found a $75 \%$ agreement between cross-shore sediment transport and volume changes measured in the intertidal zone. This relationship was especially good during calm conditions. However, there is still a need for the validation of the accuracy of acoustic sensors and the effect of variations in grain size and turbulence on these sensors remains unclear.

Results from previous research thus suggest that net transport rates based on optical or acoustic backscatter are reasonable, but not perfect. One of the causes for errors in measured suspended sediment transport rates is that transport is rarely measured very close to the bed. The deployment of instruments in shallow water often results in either burial of the instruments or them being too far from the bed (Hughes et al., 1997; Masselink et al., 2009) due to high turbulence and suspension levels as well as rapidly changing bed levels. As a result, swash transport is rarely included in field measurements, resulting in large errors (e.g. Emmanuel et al., 2009). Furthermore, measured sediment transport rates may be inaccurate, because of variations in particle size for example. Therefore, it is strongly encourages to measure particle size simultaneously and to correct the measurements for variations in it. Particle size distributions can be measured with water samples, but this is very labour intensive. It can also be done with a sensor like the Laser In-Situ Scattering and Transmissometry (LISST), that measures turbidity and in-situ particle size distribution (e.g. Mikkelsen and Pejrup, 2001). As an example, acoustic backscatter is compared to optical backscatter and particle size based on LISST measurements in Fig. 6 (Brand et al., 2019a). All were measured at $35 \mathrm{~cm}$ above the bed around the low water line of a macro-tidal, sandy beach (Groenendijk, Belgium). Acoustic backscatter was corrected for transmission loss due to spreading and absorption. Optical backscatter was converted to sediment concentration based on a calibration with water samples. In this example, the acoustic sensor clearly overestimated the suspended sediment concentration when the particle size was large $(>63 \mu \mathrm{m})$. It was found that the acoustic backscatter measurements were barely affected by turbulence. Hence, this example shows that measurements of particle size are important when acoustic backscatter is used to determine the suspended sediment concentration.

\section{Cross-checking bed load and total load measurements}

Bed load transport can make up more than half of the total load transport (Tonk and Masselink, 2005; Masselink et al., 2008), but measuring techniques for bed load transport are limited. Bed load transport can be studied with streamer traps or sand tracer experiments, but these methods are labour intensive and not very successful in quantifying transport. For example, Hughes et al. (1997) tested the streamer traps over one tidal cycle in relation to beach topography measurements with rods. They found that the transport rates were 2-3 orders of magnitude larger than the observed topographic changes. Masselink et al. (2009) measured sediment transport with streamer traps in combination with topography measurements with ultrasonic bed level sensors that continuously measure the bed elevation. In this study, the transport fluxes derived from the bed level sensors were larger than those from the traps. This was attributed to undersampling of the bed load transport due to gaps between the bed and the trap and obstruction of the bed load transport by the trap.

Recently, sand ripple profilers have been used to measure bed load transport in the intertidal zone. Masselink et al. (2008) used one in combination with measurements of suspended sediment transport and topographic change. Thanks to the use of the sand ripple profiler a reasonably good correlation between measured sediment transport and topographic change was obtained, because the bed load transport made up more than half of the total load. This technique is thus very promising, but more studies with this equipment are needed to reaffirm these results under different conditions.

Since it remains difficult to quantify bed load transport, it is often 
predicted instead. Predictions of sediment transport have been tested by comparing them to sand tracer experiments on many occasions. On lowenergy beaches the measured sediment transport rates can be three to ten times larger than the predicted rates (e.g. Ciavola et al., 1997; Nordstrom et al., 2003; Tonk and Masselink, 2005; Silva et al., 2007). On high-energy beaches the measured sediment transport is a few times lower than the predicted rates (Bertin et al., 2008). In general, measured sediment transport seems more often significantly over- or underestimated than predicted correctly with any of the existing predictive formulas (Fernández-Fernández et al., 2016).

Sediment transport predictions have also been compared to measurements of suspended sediment transport and topography measurements (Tonk and Masselink, 2005; Masselink et al., 2008; Emmanuel et al., 2009). Large differences were found when comparing them quantitatively. Bagnold-type formulas predict considerably smaller rates than the actual rates under calm wave conditions (Gallagher et al., 1998; Masselink et al., 2008; Emmanuel et al., 2009). These type of predictions work better under energetic wave conditions. This is mainly due to the exclusion of the swash zone in these predictions (Masselink et al., 2009; Emmanuel et al., 2009). Predictive formulas based on wave characteristics (e.g. CERC, 1984; Kamphuis, 1991) can predict currents rather accurately, but they perform less in predicting the cross-shore variation in sediment concentration (Van Maanen et al., 2009). As a result, their main application is for longshore sediment transport (Tonk and Masselink, 2005; Rogers and Ravens, 2008; Esteves et al., 2009). They are often far off when used to predict cross-shore sediment transport, especially for storm, but also for calm conditions (Bayram et al., 2001; Van Maanen et al., 2009).

In conclusion, predictive formulas are reasonably good in estimating the direction of long- and cross-shore sediment transport. However, at the moment they should be used with care when calculating sediment concentrations and thus transport rates, because of them often significantly over- or underestimating the transport. Under energetic conditions sediment transport is often overpredicted. Under calm conditions sediment transport is often underpredicted. The improvement of predictive formulas is ongoing, which will allow to verify measured transport rates or to calculate bed load transport in the future.

\section{Matching the scale of different measurements}

It has become clear that it is very difficult to accurately quantify suspended sediment and bed load transport. However, differences in net sediment transport and beach volume changes may also be due to mismatches between sediment transport and topography measurements. When comparing them, it is often assumed that sediment only enters or leaves the intertidal beach by underwater transport across the low water line, while wind-driven transport or gradients in alongshore sediment transport may also result in topographic changes in the intertidal zone. In addition, sediment transport and topographic change are rarely measured on the same temporal and/or spatial scale (Fig. 7, e.g. Sénéchal et al., 2011). Sediment transport is usually measured at one or a few cross-shore locations in the intertidal zone, whereas topography is often measured across, and sometimes along, the entire intertidal zone. To get insight in the spatial pattern of sediment transport some researchers install multiple measuring frames in cross- or alongshore direction (e.g. Masselink et al., 2009). However, equipment is costly, limiting the number of locations where sediment transport can be measured. Grain size trend analysis and sand tracer experiments can also be used to get some insight in spatial patterns in sediment transport, but they are usually not quantitative.

Most studies in which sediment transport observations were compared to beach volume changes used cross-shore topographic profiles to quantify beach volumes. However, it was proven that a strong alongshore variability in topographic response to hydrodynamic forcing may exist (Theuerkauf and Rodriguez, 2012). This may explain why studies in which the topography was measured with a high spatial resolution

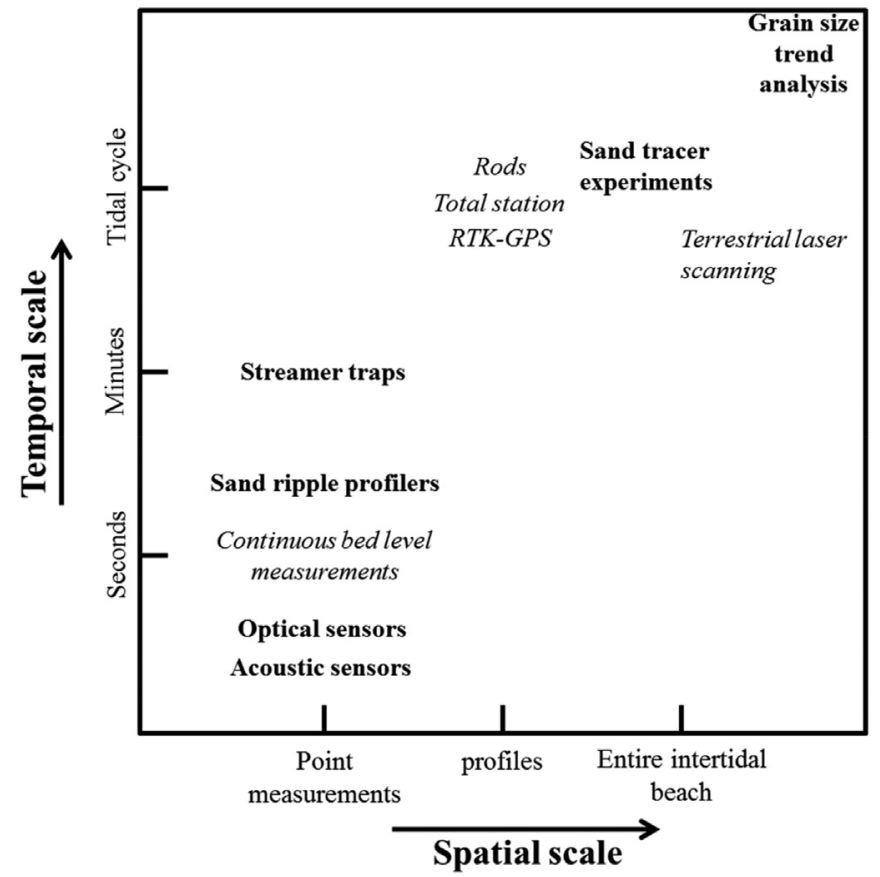

Fig. 7. Temporal and spatial scale of different measuring techniques. Methods to measure sediment transport are in bold and to measure topography in italic.

(Masselink et al., 2009) perform better than studies with a low spatial resolution (e.g. Hughes et al., 1997; Masselink et al., 2008) when comparing measured sediment transport and topographic changes. However, studies based on full beach surveys show even better correlations between measured transport rates and beach volume changes. Brand et al. (2019b) recently compared sediment transport measured with optical and acoustic sensors to volume changes obtained from a static terrestrial laser scanner. They found a good relationship between the two, with $75 \%$ of the daily observations in the same direction and within $2 \times$ over- or underestimation, especially during calm conditions. Based on previous studies it is thus highly recommended to survey the full beach topography with a laser scanner or with photogrammetry. If this is not possible because of restrictions in time and resources, it is recommended to survey many closely spaced profiles.

Apart from differences in spatial scale, there is usually also a mismatch in the frequency of sediment transport and beach topography measurements (Fig. 7). Sediment transport measurements are often (quasi-) continuous, whereas beach topography is generally only measured once or twice a day during low tide. Measured topographic changes in the intertidal zone thus reflect time-integrated sediment transport. However, instantaneous transport rates can be highly variable on a timescale of seconds and integrating them over time can be problematic. Sediment transport rates can be large over a matter of seconds and by averaging them over a tidal cycle errors are easily made (Duncan, 1964; Masselink et al., 2009). Some studies succeeded in measuring topographic change in the swash zone over individual swash events (Waddell, 1976; Sallenger and Richmond, 1984; Baldock et al., 2005; Turner et al., 2008). However, continuously measuring topographic change is difficult in the remainder of the intertidal zone. Continuous bed level measurements can be carried out with acoustic equipment (C. Berni et al., 2009a, Emmanuel et al., 2009), pressure sensors (C. Berni et al., 2009a), or the newly developed ultrasonic sensors (Turner et al., 2008). With such measurements the evolution of the bed level over time can be revealed, which is illustrated in Fig. 8. From this example, it becomes clear that topographic changes can be large ( $>15 \mathrm{~cm}$ in this case) over a period of seconds to minutes (Masselink et al., 2009). A downside of this measuring technique is that it measures the topography only very locally, however Masselink et al. 


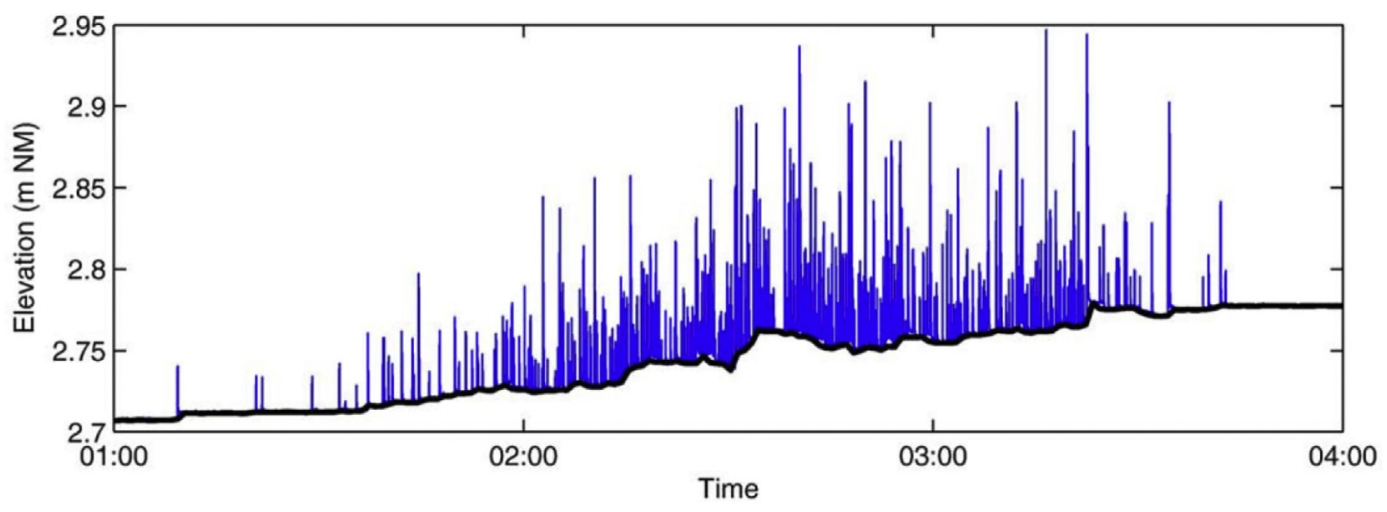

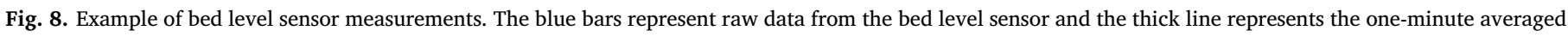

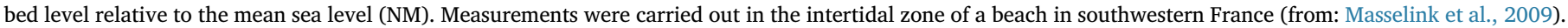
(For interpretation of the references to colour in this figure legend, the reader is referred to the web version of this article.)

(2009) solved this by installing 45 of these sensors in an array of 3 cross-shore profiles. Continuous bed level measurements are thus a valuable addition to intertidal measurements, especially when multiple are installed along and across the beach.

Another drawback of only measuring the beach topography at low tide is that topographic changes may also result from wind-driven transport. Aeolian transport has been studied in the intertidal zone on various occasions (e.g. Sarre, 1989; Anthony et al., 2009), but is rarely considered as a part of the sediment budget together with topography and underwater measurements. Brand et al. (2019b) found that winddriven transport was insignificant compared to underwater transport, even during energetic onshore wind conditions. However, in other studies significant erosion/accretion was attributed to transport by wind (e.g. Almeida et al., 2012). Both studies did not verify their findings with in-situ measurements of wind-driven transport though. The contribution of aeolian transport thus remains an uncertainty in the sediment budget of the intertidal zone.

\section{Conclusion}

The intertidal zone is among the most dynamic environments and constantly grows and erodes in response to waves, currents, and wind. Accurate measurements of sediment transport and resulting topographic changes are essential to understand the morphodynamics of the intertidal zone. In general, field investigations in the intertidal zone consist of measurements of flow velocity and suspended sediment concentrations at one or a few locations across the beach and daily topography measurements of several cross-shore profiles. However, it appears to be difficult to relate sediment transport and topographic changes with such a measuring set-up. Measured sediment transport rates are often in a different order of magnitude or even in a different direction than transport rates derived from topographic changes. To improve sediment transport and topography measurements, it is recommended to:

1. Measure sediment transport at multiple locations along and across the intertidal zone. It is recognized that this is very costly and that research budgets do not always allow for this. However, it is very valuable to know sediment transport rates at multiple locations in the intertidal zone. Two measuring locations in the alongshore direction already allow to investigate gradients in alongshore sediment transport and will result in a better approximation of the net sediment transport to or away from the intertidal zone.

2. Measure suspended sediment transport over the entire water column at beaches with strong mixing of the sediment, such as beaches with strong tidal currents or energetic waves. This can be done with an array of OBS or an ASM on micro- and meso-tidal beaches. On macro-tidal beaches, the suspended sediment concentration over the water column can be estimated based on acoustic backscatter.

3. Improve sensors to measure bed load transport and suspended sediment transport near the bed and improve predictive formulas for sediment transport. It is currently difficult to measure sediment transport close to the bed for both suspended and bed load transport. Sand ripple profilers may partially solve this problem, but field experiments with this equipment are still scarce. Meanwhile, predictive formulas are often used to estimate bed load transport, but these appear to be highly unreliable. Hence, it is recommended to improve both measuring techniques for in-situ near-bed transport and predictive formulas.

4. Measure the full beach topography on beaches with alongshore variability in beach topography, such as on beaches with cusps or nourishments. This can be done, for example, with static or mobile (airborne or terrestrial) laser scanning or photogrammetry from a UAV.

5. Correct (especially acoustic) measurements of suspended sediment concentration for grain size and turbulence. Measurements of suspended sediment concentration with optical or acoustic equipment are sensitive to grain size. Additionally, acoustic measurements are sensitive to turbulence. These measurements can be greatly improved when they are corrected for these parameters, especially the measurements with acoustic backscatter.

6. Measure beach topography over time. Sediment transport is usually measured continuously over a tidal cycle, whereas the beach topography is only measured at low tide which results in mismatches between the two. It is helpful to add continuous bed level measurements to an intertidal campaign in order to obtain a better relationship between them and to get a better understanding on the intertidal beach morphodynamics on a small scale (seconds to hours). If the beach topography is only measured during low tide, it is advised to investigate aeolian transport if wind conditions are energetic.

\section{Declaration of Competing Interest}

None.

\section{Acknowledgements}

This research is part of the CREST project, funded by the Strategic 
Basic Research (SBO) program of Instituut voor Innovatie door Wetenschap en Technologie (IWT).

\section{References}

Aagaard, T., Davidson-Arnott, R., Greenwood, B., Nielsen, J., 2004. Sediment supply from shoreface to dunes: linking sediment transport measurements and long-term morphological evolution. Geomorphology 60, 205-224.

Aagaard, T., Kroon, A., Andersen, S., Møller Sørensen, R., Quartel, S., Vinther, N., 2005. Intertidal beach change during storm conditions, Egmond, the Netherlands. Mar. Geol. 218, 65-80.

Aagaard, T., Hughes, M., Baldock, T., Greenwood, B., Kroon, A., Power, H., 2012. Sediment transport processes and morphodynamics on a reflective beach under storm and non-storm conditions. Mar. Geol. 326-328, 154-165.

Albers, T., von Lieberman, N., 2010. Morphodynamics of Wadden Sea areas - field measurements and modeling. Int. J. Ocean Clim. Syst. 1, 123-132.

Almeida, L.P., Vousdoukas, M.V., Ferreira, Ó., Rodrigues, B.A., Matias, A., 2012. Thresholds for storm impacts on an exposed sandy coastal area in southern Portugal. Geomorphology 143-144, 3-12.

Andrade, F., Ferreira, M.A., 2006. A simple method of measuring beach profiles. J. Coast. Res. 22, 995-999.

Anthony, E.J., Ruz, M.-H., Vanhée, S., 2009. Aeolian sand transport over complex intertidal bar-trough beach topography. Geomorphology 105, 95-105.

Bagnold, R.A., 1947. Sand movement by waves: some small-scale experiments with sand of very low density. J. Inst. Civil Eng. 5554, 447-469.

Bagnold, R.A., 1963. Mechanics of marine sedimentation. In: Hill, M.L. (Ed.), The Sea: Ideas and Observations. 3. Wiley Interscience, New York, pp. 507-528.

Bailard, J.A., 1984. A simplified model for longshore sediment transport. Proc. In: Edge, B.L. (Ed.), 19th Conf. On Coastal Engineering. ASCE, Reston, VA, pp. 1454-1470.

Baldock, T.E., Barnes, M.P., Hughes, M.G., 2005. Field observations of instantaneous cross-shore free surface profiles and flow depths in the swash zone. In: Proceedings of Coastal Dynamics 2005. ASCE.

Battisto, G.M., Friedrichs, C.T., Miller, H.C., Resio, D.T., 1999. Response of OBS to Mixed Grain Size Suspensions during Sandy Duck'97. Coastal Sediment Conference 99. ASCE, New York, pp. 297-312.

Bayram, A., Larson, M., Miller, H.C., Kraus, N.C., 2001. Cross-shore distribution of longshore sediment transport: comparison between predictive formulas and field measurements. Coast. Eng. 44, 79-99.

Bell, P.S., Thorne, P.D., Williams, J.J., 1998. Acoustic measurements of sand ripple profile evolution under controlled wave conditions. In: Proceedings of the $4^{\text {th }}$ European Conference on Underwater Acoustics. 1. pp. 353-358.

Berni, C., Mignot, E., Michallet, H., Dalla-Costa, C., Grasso, F., Lagauzère, M., 2009a. Diversity of bed evolution at wave and tidal scales on Truc-Vert beach. J. Coast. Res. 56, 1726-1730 Special Issue.

Berni, J.A.J., Zarco-Tejada, P.J., Suarez, L., Fereres, E., 2009b. Thermal and narrowband multispectral remote sensing for vegetation monitoring from an unmanned aerial vehicle. IEEE Trans. Geosci. Remote Sens. 47, 722-738.

Bernstein, D.J., Freeman, C., Forte, M.F., Park, J.Y., Gayes, P.T., Mitasova, H., 2003. Survey design analysis for three-dimensional mapping of beach and nearshore morphology. In: Proceedings of the Coastal Sediment'03. USA, St. Petersburg, Florida.

Bertin, X., Castelle, B., Chaumillon, E., Butel, R., Quique, R., 2008. Longshore transport estimation and interannual variability at a high-energy dissipative beach: St. Trojan beach, SW Oléron Island, France. Cont. Shelf Res. 28, 1316-1332.

Brand, E., Montreuil, A.-L., Chen, M., 2019a. The effect of turbulence and particle size on suspended sediment concentration measurements in the intertidal zone. In: Coastal Sediments 2019, Tampa, St. Pete, Florida, USA.

Brand, E., De Sloover, L., De Wulf, A., Montreuil, A.-L., Vos, S., Chen, M., 2019b. Crossshore suspended sediment transport in relation to topographic changes in the intertidal zone of a Macro-Tidal Beach (Mariakerke, Belgium). J. Mar. Sci. Eng. 7, 1-16.

Butt, T., Russell, P., Puleo, J., Masselink, G., 2005. The application of Bagnold-type sediment transport in the swash zone. Cont. Shelf Res. 24, 757-771.

Caldwell, J.M., 1956. Wave action and sand movement near Anaheim Bay, California. In: U.S. Army Beach Erosion Board, Tech. Mem. 68 (21 pp).

Cartier, A., Héquette, A., 2015. Vertical distribution of longshore sediment transport on barred macrotidal beaches, norther France. Cont. Shelf Res. 93, 1-16.

CERC (USACE Waterways Experiment Station"s Coastal Engineering Research Center), 1984. Shore Protection Manual. U.S. Government Printing Office, Washington, DC.

Ciavola, P., Taborda, R., Ferreira, O., Dias, J.A., 1997. Field measurements of longshore sand transport and control processes on a steep meso-tidal beach in Portugal. J. Coast. Res. 13, 1119-1129.

Cohn, N., Ruggiero, P., de Vries, S., Garcìa-Medina, G., 2017. Beach growth driven by intertidal sandbar welding. Coastal Dynamics 2017, 1059-1069.

Delacourt, C., Alleman, P., Jaud, M., Grandjean, P., Deschamps, A., Ammann, J., Cuq, V., Suanez, S., 2009. DRELIO: an unmanned helicopter for imaging coastal areas. J. Coast. Res. 56, 1489-1493 Special Issue.

Delgado, I., Alcantara, C.J., Alejo, I., Alonso, I., Louzao, M., 2002. Influence of hydrodynamics and sedimentary characteristics of Barqueiro Ria on Arealonga beach dynamics. J. Coast. Res. 36, 231-239.

Dohmen-Janssen, M., Hanes, D.M., 2002. Sheet flow dynamics under monochromatic nonbreaking waves. J. Geophys. Res. 107, 1-21.

Downing, J.P., Sternberg, R.W., Lister, C.R.B., 1981. New instrumentation for the investigation of sediment suspension processes in the shallow marine environment. Mar. Geol. 42, 19-34.

Duncan, J.R., 1964. The effects of water table and tidal cycle on swash-backwash sediment distribution and beach profile development. Mar. Geol. 2, 186-197.

Eamer, J.B.R., Walker, I.J., 2013. Quantifying spatial and temporal trends in beach-dune volumetric changes using spatial statistics. Geomorphology 191, 94-108.

Emery, K.O., 1961. A simple method of measuring beach profiles. Limnol. Oceanogr. 6, 90-93.

Emmanuel, I., Parisot, J.P., Michallet, H., Barthélemy, E., Sénéchal, N., 2009. Sediment transport particular events and beach profile response. J. Coast. Res. 56, 1766-1770 Special Issue.

Esteves, L.S., Lisniowski, M.A., Wiliams, J.J., 2009. Measuring and modelling longshore sediment transport. Estuar. Coast. Shelf Sci. 83, 47-59.

Fernández-Fernández, S., Baptista, P., Martins, V.A., Silva, P.A., Abreu, T., Pais-Barbosa, J., Bernardes, C., Miranda, P., Rocha, M.V.L., Santos, F., Bernabeu, A., Rey, D., 2016. Longshore transport estimation on ofir beach in northwest portugal: sand-tracer experiment. J. Waterw. Port. Coast. Eng. 142, 04015017.

Furgerot, L., Mouaze, D., Tessier, B., Perez, L., Haquin, S., Weill, P., Crave, A., 2016. Sediment transport induced by tidal bores. An estimation from suspended matter measurements in the Sée River (Mont-Saint-Michel Bay, northwestern France). Compt. Rendus Geosci. 348, 432-441.

Gallagher, E.L., Elgar, S., Guza, R.T., 1998. Observations of sand bar evolution on a natural beach. J. Geophys. Res. 103, 3203-3215.

Gao, S., Collins, M., 1991. A critique of the McLaren Method for defining sediment transport paths: discussion. J. Sediment. Petrol. 61, 143-146.

Gao, S., Collins, M., 1992. Sand sediment transport patterns inferred from grain-size trends based upon definition of "transport vectors". J. Sediment. Petrol. 80, 47-60.

Gao, S., Collins, M., 1994. Analysis of grain size trends, for defining sediment transport pathways in marine environments. J. Coast. Res. 10, 70-78.

Gartner, J.W., 2004. Estimating suspended solids concentrations from backscatter intensity measured by acoustic Doppler current profiler in San Francisco Bay, California. Mar. Geol. 211, 169-187.

Hails, J.R., 1974. A review of some current trends in nearshore research. Earth-Sci. Rev. $10,171-202$.

Havinga, H., 1982. Bed Load Determination by Dune Tracking. Dir. Water Management and Water Motion District South East, Rijkswaterstaat, The Netherlands.

Hoefel, F., Elgar, S., 2003. Wave-induced sediment transport and sand bar migration. Science 299, 1885-1887.

Houser, C., Greenwood, B., Aagaard, T., 2006. Divergent response of an intertidal swash bar. Earth Surf. Process. Landf. 31, 1775-1791.

Hughes, M.G., Masselink, G., Brander, R.W., 1997. Flow velocity and sediment transport in the swash zone of a steep beach. Mar. Geol. 138, 91-103.

Huising, E.J., Gomes Pereira, L.M., 1998. Errors and accuracy estimates of laser data acquired by various laser scanning systems for topographic applications. ISPRS J. Photogramm. Remote Sens. 53, 245-261.

Incoul, A., Nuttens, T., De Maeyer, P., Seube, N., Stal, C., Touzé, T., De Wulf, A., 2014. Mobile laser scanning of intertidal zones of beaches using an amphibious vehicle. In: INGEO 2014 - 6th International Conference on Engineering Surveying, Prague, Czech Republic, April 3-4, pp. 87-92.

Inman, D.L., 1949. Sediment trap studies of suspended material near the surf zone. Scripps Inst. Oceanogr. Q., Prog. Rep. To U.S. Army Corps Eng. BEB 2, 5-6.

Inman, D.L., Bagnold, R.A., 1963. Littoral processes. In: Hill, M.L. (Ed.), The Sea: Ideas and Observations. 3. Wiley Interscience, New York, pp. 507-528.

Jaffe, B.E., Sternberg, R.W., Sallenger, A.H., 1984. Role of suspended sediment in shorenormal beach profile changes. In: Proc. lgth. Int. Coastal Eng. Conf., Houston, TX. ASCE, New York, pp. 1983-1996.

Jaud, M., Delacourt, C., Allemand, P., Deschamps, A., Cancouët, R., Ammann, J., Grandjean, P., Suanez, S., Fichaut, B., Cuq, V., 2011. Comparison of some very high resolution remote sensing techniques for the monitoring of a sandy beach. AGU, Fall Meeting 2011.

Kamphuis, J.W., 1991. Alongshore sediment transport rate. J. Waterw. Port. Coastal. Ocean Eng., ASCE 117, 624-640.

Komar, P.D., Inman, D.L., 1970. Longshore sand transport on beaches. J. Geophys. Res. (1896-1977) 75, 5914-5927.

Kraus, N.C., 1987. Application of portable traps for obtaining point measurements of sediment transport rates in the surf zone. J. Coast. Res. 3, 139-152.

Lanckriet, T., Puleo, J.A., Waite, N., 2013. A conductivity concentration profiler for sheet flow sediment transport. J. Ocean Eng. 38, 55-70.

Le Roux, J.P., 1994. An alternative approach to the identification of sand sediment transport paths based on a grain-size trends. Sediment. Geol. 94, 97-107.

Levoy, F., Monthort, O., Rousset, H., 1994. Quantification of longshore transport in the surfzone on macrotidal beaches. Fields experiments along the western coast of Cotentin (Normandy, France). In: ASCE (Ed.), Proceedings of the 24th International Conference on Coastal Engineering, Kobe, Japan, pp. 2282-2296.

Levoy, F., Montfort, O., Larsonneur, C., 1997. Quantification des debits solides sur les plages macrotidales à l'aide de traceurs fluorescents, application à la côte ouest du Cotentin. Oceanol. Acta 20, 811-822.

Masselink, G., 1992. Longshore variation of grain size distribution along the coast of the Rhône delta, Southern France: a test of "McLaren model". J. Coast. Res. 8, 286-291.

Masselink, G., Hughes, M., 1998. Field investigation of sediment transport in the swash zone. Cont. Shelf Res. 18, 1179-1199.

Masselink, G., Russell, P., 2006. Flow velocities, sediment transport and morphological change in the swash zone of two contrasting beaches. Mar. Geol. 227, 227-240.

Masselink, G., Austin, M., Tinker, J., O'Hare, T., Russell, P., 2008. Cross-shore sediment transport and morphological response on a macrotidal beach with intertidal bar morphology, Truc Vert, France. Mar. Geol. 251, 141-155.

Masselink, G., Russell, P., Turner, I., Blenkinsopp, C., 2009. Net sediment transport and morphological change in the swash zone of a high-energy sandy beach from swash event to tidal cycle time scales. Mar. Geol. 267, 18-35. 
Masselink, G., Hughes, M.G., Knight, J., 2011. Introduction to Coastal Processes \& Geomorphology. Hodder education, London, UK.

McLaren, P., 1981. An interpretation of trends in grain-size measures. J. Sediment. Petrol. $51,611-624$.

McLaren, P., Bowles, D., 1985. The effects of sediment transport on grain-size distributions. J. Sediment. Petrol. 55, 457-470.

McLean, S.R., Ribberink, J.S., Dohmen-Janssen, C.M., Hassan, W.N., 2001. Sand Transport in Oscillatory Sheet Flow with mean current. J. Waterw. Port Coast. Ocean Eng. 127, 141-151.

Medvedev, V.C., Aibulatov, N.A., 1956. The use of 'labelled' sand to study the movement of material. Izv. Akad. Nauk. SSSR Ser. Geogr. 4, 99-102.

Merckelbach, L.M., Ridderinkhof, H., 2006. Estimating suspended sediment concentration using backscatterance from an acoustic Doppler profiling current meter at a site with strong tidal currents. Ocean Dyn. 56, 135-168.

Mikkelsen, O.A., Pejrup, M., 2001. The use of a LISST-100 laser particle sizer for in-situ estimates of floc size, density and settling velocity. Geo-Mar. Lett. 20, 187-195.

Nauw, J.J., Merckelbach, L.M., Ridderinkhof, H., van Aken, H.M., 2014. Long-term ferrybased observations of the suspended sediment fluxes through the Marsdiep inlet using acoustic Doppler current profilers. J. Sea Res. 87, 17-29.

Nordstrom, K.F., Jackson, N.L., Allen, J.R., Sherman, D.J., 2003. Longshore sediment transport rates on a microtidal estuarine beach. J. Waterw. Port Coast. Ocean Eng. 129, 1-4.

Parisot, J.P., Capo, S., Castelle, B., Bujan, S., Moreau, J., Gervais, M., Réjas, A., Hanquiez, V., Almar, R., Marieu, V., Gaunet, J., Gluard, L., George, I., Nahon, A., Dehouck, A., Certain, R., Barthe, P., Le Gall, F., Bernardi, P.J., Le Roy, R., Pedreros, R., Delattre, M., Brillet, J., Sénéchal, N., 2009. Treatment of topographic and bathymetric data acquired at the Truc-Vert Beach during the ECORS Field Experiment., J. Coast. Res., Special Issue 56, 1786-1790.

Pedreros, R., Howa, H.L., Michel, D., 1996. Application of grain size trend analysis for the determination of sediment transport pathways in intertidal areas. Mar. Geol. 135, $35-49$.

Pietro, L.S., O’Neal, M.A., Puleo, J.A., 2008. Developing terrestrial-LiDAR-based digital elevation models for monitoring beach nourishment performance. J. Coast. Res. 24, 1555-1564.

Poizot, E., Mear, Y., Thomas, M., Garnaud, S., 2006. The application of geostatistics in defining the characteristic distance for grain size trend analysis. Comput. Geosci. 32, 360-370.

Ribberink, J.S., Al-Salem, A., 1992. Time-dependent sediment transport phenomena in oscillatory boundary-layer flow under sheet-flow conditions. In: Delft Hydraulics, The Netherlands, Report H840.20 Part VI (Kustgenese/MaST).

Rogers, A.L., Ravens, T.M., 2008. Measurement of Longshore Sediment Transport rates in the Surf Zone on Galveston Island, Texas. J. Coast. Res. 2, 62-73.

Sallenger, A.H., Richmond, B.M., 1984. High-frequency sediment level oscillations in the swash zone. In: Greenwood, B., Davis Jr.R.A. (Eds.), Hydrodynamics and Sedimentation in Wave-dominated Coastal Environments. 60. Marine Geology, pp. 155-164.

Sarre, R.D., 1989. Aeolian sand drift from the intertidal zone on a temperate beach: potential and actual rates. Earth Surf. Process. Landf. 14, 247-258.

Schoonees, J.S., Theron, A.K., 1995. Accuracy and Applicability of the SPM Longshore Transport Formula. Proceedings of the $24^{\text {th }}$ ICCE. ASCE, New York, pp. 2595-2609.

Schoonees, J.S., Theron, A.K., 1996. Improvement of the most accurate longshore transport formula. $25^{\text {th }}$ ICCE Orlando. USA 3652-3665.

Sedrati, M., Anthony, E.J., 2007. Storm-generated morphological change and longshore sand transport in the intertidal zone of a multi-barred macrotidal beach. Mar. Geol. 244, 209-229.

Sénéchal, N., Abadie, S., Gallagher, E., MacMahan, J., Masselink, G., Michallet, H., Reniers, A., Ruessink, G., Russell, P., Sous, D., Turner, I., Ardhuin, F., Bonneton, P., Bujan, S., Capo, S., Certain, R., Pedreros, R., Garlan, T., 2011. The ECORS-Truc Vert'08 nearshore field experiment: presentation of a three-dimensional morphologic system in a macro-tidal environment during consecutive extreme storm conditions. Ocean Dyn. 61, 2073-2098.

Silva, A., Taborda, R., Rodrigues, A., Duarte, J., Cascalho, J., 2007. Longshore drift estimation using fluorescent tracers: New insights from an experiment at Comporta Beach, Portugal. Mar. Geol. 240, 137-150.

Simons, D.B., Richardson, E.V., Nordin, C.F., 1965. Bed load equation for ripples and dunes. In: U.S. Geol. Survey Prof. Paper 462 H, Washington, USA.

Stépanian, A., Vlaswinkel, B., Levoy, F., Larsonneur, C., 2001. Fluorescent tracer experiment on a macrotidal ridge and runnel beach: A case study at Omaha beach,
North France. In: Coastal Dynamics. 2001. Lund, Sweden, pp. 1017-1027.

Swales, A., 2002. Geostatistical estimation of short-term changes in beach morphology and sand budget. J. Coast. Res. 18, 338-351.

Terry, R.D., 1951. Suspended Sediment Study of Surf at Huntington Beach. California. Univ., S. Calif., pp. 21 unpublished report in Sedimentation.

Theuerkauf, E.J., Rodriguez, A.B., 2012. Impacts of Transect Location and Variations in Along-Beach Morphology on measuring volume Change. J. Coast. Res. 28, 707-718.

Thorne, P.D., Vincent, C.E., Hardcastle, P.J., Rehman, S., Pearson, N., 1991. Measuring suspended sediment concentration using acoustic backscatter devices. Mar. Geol. 98, $7-16$.

Thorne, P.D., Davies, A.G., Bell, P.S., 2009. Observations and analysis of sediment diffusivity profiles over sandy rippled beds under waves. J. Geophys. Res. 114, 1-16.

Thornton, E.B., 1968. A field investigation of sand transport in the surf zone. In: Proc. Conf. Coastal Eng., 11 ${ }^{\text {th }}$, Am. Soc. Civ. Eng. 1. pp. 335-351.

Thornton, E.B., Humiston, R.T., Birkemeier, W., 1996. Bar/trough generation on a natural beach. J. Geophys. Res. 101, 12097-12110.

Tonk, A., Masselink, G., 2005. Evaluation of longshore transport equations with obs sensors, streamer traps and fluorescent tracer. J. Coast. Res. 21, 915-931.

Turner, I.L., Russell, P.E., Butt, T., 2008. Measurements of wave-by-wave bed-levels in the swash zone. Coast. Eng. 55, 1237-1242.

Van Maanen, B., de Ruiter, P.J., Ruessink, B.G., 2009. An evaluation of two along-shore transport equations with field measurements. Coast. Eng. 56, 313-319.

Van Rijn, L.C., 1993. In: ... (Ed.), Principles of Sediment Transport in Rivers and Estuaries and Coastal Seas. Aqua Publications.

Van Rijn, L.C., 2014. A simple general expression for longshore transport of sand, gravel and shingle. Coast. Eng. 90, 23-39.

Vijverberg, T., Winterwerp, J.C., Aarninkhof, S.G.J., Drost, H., 2011. Fine sediment dynamics in a shallow lake and implication for design of hydraulic works. Ocean Dyn. 61, 187-202.

Vos, S.E., Lindenbergh, R.C., de Vries, S., 2017. Coastscan: Continuous monitoring of coastal change using terrestrial laser scanning. In: Proceedings of the Coastal Dynamics 2017, Helsingør, Denmark, 12-16 June 2017, pp. 1518-1528.

Vos, S.E., Hobbelen, R.N.P., Spaans, L., de Vries, S., Lindenbergh, R.C., 2019. Crossshore sand patterns in the intertidal zone: a case study with permanent laser scanning at Kijkduin beach. In: Proceedings of Coastal Sediments 2019, Tampa, USA, 27-31 May 2019, pp. 287-295.

Voulgaris, G., Mason, T., Collins, M.B., 1996. An energetics approach for suspended sand transport on macrotidal ridge and runnel beaches. In: Proceedings of the $25^{\text {th }}$ International Conference on Coastal Engineering, Orlando, FL, USA, 2-6 September 1996, pp. 3948-3961.

Voulgaris, G., Simmonds, D., Michel, D., Howa, H., Collins, M.B., Huntley, D., 1998. Measuring and modelling sediment transport on a macrotidal ridge and runnel beach: an intercomparison. J. Coast. Res. 14, 315-330.

Vousdoukas, M.I., Kirupakaramoorthy, T., Oumeraci, H., de la Torre, M., Wübbold, F., Wagner, B., Schimmels, S., 2014. The role of combined laser scanning and video techniques in monitoring wave-by-wave swash zone processes. Coast. Eng. 83, $150-165$.

Waddell, E., 1976. Swash-groundwater-beach profile interactions. In: Davis, R.A., Ethington, R.L. (Eds.), Beach and Nearshore Sedimentation. Society of Economic Paleontologists and Mineralogists, Oklahoma, pp. 115-125.

Wang, P., Ebersole, B.A., Smith, E.R., Johnson, B.D., 2002. Temporal and spatial variations of surf-zone currents and suspended sediment concentration. Coast. Eng. 46, $175-211$.

Watts, G.M., 1953. Development and field tests of a sampler for suspended sediment in wave action. BEB Tech. Mem. 34-41.

Weiss, A., Clark, S.P., Rennie, C.D., Moore, S.A., Ahmari, H., 2015. Estimation of total suspended solids concentration from aDcp backscatter and hydraulic measurements. J. Hydraul. Res. 53, 670-677.

Westoby, M.J., Brasington, J., Glasser, N.F., Hambrey, M.J., Reynolds, J.M., 2012 "Structure-from-motion" photogrammetry: a low-cost, effective tool for geoscience applications. Geomorphology 179, 300-314.

Wright, F.F., 1962. The development and application of a fluorescent marking technique for tracing sand movements on beaches. In: Office of Naval Research, Geography Brand Technical Report, No. 2 NR 388-057, (29 pp).

Zhang, S., Jia, Y., Wang, Z., Wen, M., Fang, L., Zhang, Y., Liu, X., Shan, H., 2018. Wave flume experiments on the contribution of seabed fluidization to sediment resuspension. Acta Oceanol. Sin. 37, 80-87. 